\title{
QÂNÛN JINÂYAT ACEH DALAM PERSPEKTIF NEGARA HUKUM INDONESIA
}

\author{
Kamarusdiana \\ Fakultas Syariah dan Hukum UIN Syarif Hidayatullah Jakarta \\ Jl. Ir. H. Juanda No. 95 Ciputat, Jakarta \\ E-mail: kamarusdiana_muhammad@yahoo.com
}

\begin{abstract}
The Jinâyat Qânûn of Aceh in the Perspective of Indonesian Legal State. Act Number 18 Year 2001 on Specific Autonomy for Aceh as the province of Nanggroe Aceh Darussalam and Act Number 11 Year 2006 on Aceh Government further confirm that the existence of Islamic law in Aceh has become national law, in terms of legal materials, law enforcement officers, as well as increasing public awareness of Islamic law in Aceh. Jinayat Qanun in Aceh province is a renewal of criminal law in Indonesia because a good law must reflect the living law in the society. Therefore, the applied law in Aceh today can be used as a model of the national legal development in Indonesia.
\end{abstract}

Keywords: qânûn, jinâyat, Islamic law, legal state

\begin{abstract}
Abstrak: Qânûn Jinâyat Aceh dalam PerspektifNegara Hukum Indonesia. Undang-Undang Nomor 18 Tahun 2001 tentang Otonomi Khusus Provinsi Daerah Istimewa Aceh sebagai Provinsi Naggroe Aceh Darussalam serta UndangUndang Nomor 11 Tahun 2006 tentang Pemerintah Aceh semakin menegaskan bahwa eksistensi hukum Islam di Aceh sudah menjadi hukum Nasional, baik dari sisi materi hukum, aparat penegak hukum, maupun peningkatan kesadaran masyarakat di Aceh akan syariat Islam. Qânûn jinâyat di Provinsi Aceh merupakan pembaruan hukum pidana di Indonesia, karena hukum yang baik harus mencerminkan hukum yang hidup dalam masyarakat itu sendiri, sehingga hukum yang berlaku di Aceh sekarang ini bisa dijadikan model pembangunan hukum di Indonesia yang majemuk, namun tetap dalam bingkai Negara hukum Indonesia.
\end{abstract}

Kata Kunci: qânûn, jinâyat, syariat Islam, negara hukum

\section{Pendahuluan}

Sebagai negara hukum (Rechtsstaat), Indonesia adalah negara yang tunduk kepada hukum dan berada di bawah hukum $^{1}$. Di dalamnya, kekuasaan negara dibatasi dan ditentukan oleh hukum, demikian pula alat-alat kelengkapannya termasuk pemerintah harus bersumber dan berakar dalam hukum. Oleh karena itu, dalam suatu negara hukum selain persamaan (equality) terdapat juga pembatasan (restriction). Batas-batas kekuasaan ini juga berubah-ubah, bergantung kepada keadaan. Namun, sarana yang dipergunakan untuk membatasi kedua kepentingan itu adalah hukum, baik negara maupun individu adalah subjek hukum yang memiliki hak dan kewajiban. Oleh karena itu, dalam suatu negara hukum kedudukan dan hubungan individu dengan negara senantiasa dalam keseimbangan, kedua-duanya mempunyai hak dan kewajiban yang dilindungi oleh hukum.

Naskah diterima: 25 Februari 2016; Direvisi: 9 Juni 2016; Disetujui untuk diterbitkan: 16 Juni 2016.

1 Rukmana Amanwinata, "Sistem Pemerintahan Indonesia", Dialektika, Vol. 2, No. 2-2001, h. 25.
Konsepsi negara hukum yang dianut Indonesia tidak hanya dari dimensi formal, melainkan dalam arti materiil atau lazim dipergunakan terminologi negara kesejahteraan (welfare state) atau "negara kemakmuran". Oleh karena itu, selaras konteks di atas maka tujuan yang hendak dicapai negara Indonesia adalah terwujudnya masyarakat adil dan makmur baik spiritual maupun materiil berdasarkan Pancasila, sehingga "disebut juga sebagai negara hukum yang memiliki karakteristik mandiri". ${ }^{2}$

Indonesia sebagai Negara hukum dalam sejarah penerapan hukumnya mengenal 3 (tiga) sumber hukum yaitu sumber hukum yang berasal dari barat, hukum Islam dan Hukum adat. Hukum Islam yang berlaku di Indonesia ternyata tidak saja yang berlaku secara yuridis formal, yakni menjadi hukum positif berdasarkan atau karena ditunjuk oleh peraturan perundang-undangan,

\footnotetext{
${ }^{2}$ Rukmana Amanwinata, "Pengaturan dan Batas Implementas Kemerdekaan Berserikat Dan Berkumpul Dalam Pasal 28 UUD 1945", Disertasi, Pascasarjana Universitas Padjadjaran, (Bandung: 1996), h. 109.
} 
namun juga yang berlaku secara normatif seperti hukum yang mengatur hubungan manusia dengan Tuhan. ${ }^{3}$ Kedua norma tersebut telah menjadi hukum yang hidup (living law) di dalam masyarakat. Hal ini meng ingat, bukan saja karena hukum Islam merupakan entitas agama yang dianut oleh mayoritas penduduk hingga saat ini, akan tetapi dalam dimensi amaliahnya di beberapa daerah telah menjadi bagian tradisi (adat) masyarakat yang terkadang dianggap sakral seperti di Sumatera Barat dikenal adanya istilah "adat bersendi syara, Syara bersendi kitabullah". ${ }^{4}$

Hukum Islam sebagai salah satu sumber hukum serta tetap hidup di masyarakat Indonesia, telah mengalami pasang surut sesuai dengan kondisi politik yang ada. Syariat Islam telah menjadi sejarah yang panjang. Semenjak zaman kerajaan-kerajaan bahkan sampai pada masa kemerdekaan penegakan Syariat Islam terus diperjuangkan khususnya di Aceh.

Syariat Islam di Aceh berkembang seiring dengan perkembangan Islam itu sendiri. Perkembangan hukum Islam di Aceh tidak dapat dilepaskan dari peran sultan yang memerintah dan memegang kekuasan pada masa itu. Peran sultan yang absolut menyebabkan agama rakyat adalah agama sultan mereka. Para raja Aceh yang sejak berdirinya kerajaan sudah menjadi pemeluk agama Islam membuat Islam menjadi agama yang dianut oleh masyarakat Aceh. Dalam kerajaan Aceh Darussalam peran keagamaan dipimpin oleh seorang ulama yang disebut Syaykh al-Islàm yang menjadi patron pelbagai kebijakan pemerintahan berkaitan dengan agama. Syaykh al-Islâm Nuruddin Ar-Raniry (1637-1641) mengarang beberapa kitab yang menjadi pegangan para hakim di seluruh wilayah kekuasan Aceh dalam memutuskan perkara. Hal yang sama juga dilakukan pada masa pemerintahan Sultanah Safiatuddin (1641-1675) dengan Syaykh alIslàm Abdurrauf Syiah Kuala (1642-1693).

Kekuasaan tidak terbatas yang dimiliki Sultan dalam melaksanakan hukum Islam menyebabkan hukum Islam yang ada di Aceh berubah menjadi adat. Sebagai adat ia terkadang melangkah jauh melebihi hukum Islam itu sendiri bahkan cenderung menjadi "hukum Sultan". Dalam konteks ini maka Sultan seolah memiliki hak yang tidak terbatas dalam melaksanakan hukum kepada orang yang bersalah, terutama orang yang tidak taat kepada sultan. Dalam Bustan al-Salatin Nuruddin ar-Raniry mengatakan:

${ }^{3}$ Muhammad Daud Ali, Hukum Islam, UUPA dan Masalahnya, dalam Cik Hasan Bisri, Bunga Rampai Peradilan Agama di Indonesia, (Bandung: Ulil Albab Press, 1997), h. 73.

${ }^{4}$ A.M. Datuk Marhun Batuah dan D.K. Bagindo Tananeh, Hukum Adat dan Adat Minangkabau, (Jakarta, N.V. Poesaka Asli, 1992), h. 16. ...segala yang berbuat khianat akan segala raja-raja tak dapat tiada datang jua ke atas mereka itu murka Allah Ta'ala fadhihat, hubaya-hubaya hal segala hamba Allah, jangan kamu berbuat khianat akan segala raja-raja, tak dapat tiada pekerjaan yang demikian itu dinyatakan Allah Ta’ala juga kepadanya.

Realitas di atas jelas kiranya Islam yang berkembang pada masa pemerintahan Sultan Iskandar Muda (16071637) dan beberapa penguasa sesudahnya diwarnai dengan Islam berperspektif tasawuf (Sehat Ihsan, 2008: 205). Namun demikian dalam beberapa dekade akhir perkembangan kerajaan juga berkembang aspek fikih. Pada masa pemerintahan Aceh berada di bawah kekuasaan sultan perempuan selama 49 tahun (16411699), Syaykh al-Islâm kerajaan, Abdurrauf As-Singkili menulis beberapa kitab yang membahas masalah hukum Islam yang kemudian menjadi dasar bagi hakim di pelbagai wilayah kekuasaan kerajaan Aceh dalam memutuskan perkara agama.

Pada masa reformasi, usaha untuk membangun hukum sesuai dengan nilai yang hidup dalam masyarakat memasuki babak baru sesuai dengan perubahan paradigma dalam kehidupan bernegara, antara lain dengan adanya amandemen UUD 1945 seperti yang dinyatakan Romli Atmasasmita:

Telah terjadi perubahan paradigma dalam kehidupan politik dan ketatanegaraan di Indonesia, yaitu dari sistem sentralistik kepada sistem otonomi. Perubahan paradigma tersebut sudah tentu berdampak terhadap sistem hukum yang dianut selama ini yang lebih banyak menitikberatkan kepada produk-produk hukum yang lebih banyak berpihak kepada kepentingan penguasa daripada kepentingan rakyat. Selain itu produk hukum yang lebih mengedepankan dominasi kepentingan pemerintah pusat daripada kepentingan pemerintah daerah.

Pada masa kemerdekaan Indonesia, keinginan untuk menjadikan Islam sebagai dasar kehidupan bermasyarakat dan bernegara terus muncul khususnya di Provinsi Aceh. Kesempatan emas usaha ini lahir pasca tumbangnya Orde Baru pada tahun 1998. Dengan runtuhnya kekuasan absolut Soeharto, pemerintahan yang lebih demokratis mulai terbangun. ${ }^{5}$

Salah satu wujudnya adalah pemberian otonomi khusus kepada daerah-daerah di seluruh Indonesia. Untuk Aceh, pada 1999 dikeluarkan Undang-Undang Nomor 44 Tahun 1999 tentang keistimewaan Aceh. Undang-Undang tersebut menjadi dasar awal penerapan Syariat Islam di Aceh setelah terkubur puluhan tahun. Dalam undang-undang ini ditegaskan pelaksanaan Syariat Islam dalam kehidupan sosial masyarakat secara menyeluruh (kâffah) merupakan salah satu di

${ }^{5}$ O'Rourke, Kevin, Reformasi: the Struggle for Power in Post-Soeharto Indonesia, (Australia: Allen \& Unwin, 2002), h. 134. 
antara empat keistimewaan Aceh yang lain. ${ }^{8}$ Ini berarti, keseluruhan dimensi kehidupan sosial kemasyarakatan di Aceh akan mendapatkan pengaturan dari hukum Syariat.

Syariat adalah hukum yang bersumber pada Alquran dan Sunah Nabi Muhammad, baik yang diambil dari pendapat dan penafsiran ulama Islam terdahulu, ulama Islam kontemporer atau hasil ijtihad (legal reasoning) ulama Aceh yang ada saat ini yang dilandasi pada konteks budaya dan masyarakat lokal Aceh. Nuansa baru dinamika bangsa saat ini ditandai dengan menguatnya posisi Daerah untuk mengatur dirinya sendiri, keistimewaan Provinsi Nangroe Aceh Darussalam (NAD) karena telah diberi kesempatan untuk menerapkan Syariat Islam.

Era reformasi ternyata telah secara serta-merta menggebrak pintu Otonomi Daerah di seluruh Indonesia, bahkan otonomi yang seluas-luasnya bagi Provinsi Aceh untuk dapat melaksanakan Syariat Islam, hal ini sejalan dengan maksud kelahiran Undang-Undang Nomor 44 Tahun 1999 tentang Penyelenggaraan Keistimewaan Provinsi Daerah Istimewa Aceh (Lembaran Negara Republik Indonesia Tahun 1999 Nomor 172, Tambahan Lembaran Negara Nomor 3839), kemudian lebih dipertegas lagi dengan lahirnya Undang-Undang Nomor 18 Tahun 2001 tentang Otonomi Khusus bagi Provinsi Daerah Istimewa Aceh sebagai Provinsi Nangroe Aceh Darussalam (NAD) (Lembaran Negara Republik Indonesia Tahun 2001 Nomor 114, Tambahan Lembaran Negara Nomor 4134).

Kedua Undang-Undang tersebut, lebih dioperasionalkan lagi oleh Keputusan Presiden Republik Indonesia (Kepres) 11 Tahun 2003 tanggal 3 Maret 2003 tentang Mahkamah Syariah dan Mahkamah Syariah Provinsi di Provinsi Nangroe Aceh Darussalam. ${ }^{6}$

Hukum Pidana Islam lahir di Provinsi Nangroe Aceh Darussalam meskipun berbeda dengan Hukum Pidana Indonesia yang berlaku secara umum di Nusantara ini. Sampai sekarang ini belum ada Qânûn khusus yang mengatur tentang Hukum Pidana Islam di Provinsi Aceh, tetapi Hukum Pidana Islam itu masih tersebar pada Qânûn-Qânûn yang ada. Setelah diteliti ternyata baru ada lima Qânûn yang memuat Hukum Pidana Islam tersebut sebagai berikut: (1) Qânûn Nomor 11 Tahun 2002, tentang Pelaksanaan Syariat Islam bidang Akidah, Ibadah, dan Syiar Islam; (2) Qânûn Nomor 12 Tahun 2003 tentang Minuman khamar dan sejenisnya; (3) Qânûn Nomor 13 Tahun 2003 tentang Maisir (perjudian); (4) Qânûn Nomor 14 Tahun 2003 tentang

${ }^{6}$ Pustaka Pelajar, Kumpulan Undang Undang Peradilan Terbaru, Cet. Ke-I, (Jogyakarta, Pustaka pelajar, 2005), h. 239.
Khalwat (Mesum); dan (5) Qânûn Nomor 7 Tahun 2004 tentang Pengelolaan zakat.

Terjadinya kekhawatiran dualisme Hukum Pidana di Provinsi Nangroe Aceh Darussalam adalah antara Hukum Pidana Indonesia secara umum di satu sisi, dan Hukum Pidana Nangroe Aceh Darussalam yang diatur lewat qânûn-qânûn sebagai implikasi dari kesempatan penerapan Syariat Islam di sisi yang lain. Nangroe Aceh Darussalam sebagai sebuah Provinsi bagian dari negara kesatuan Republik Indonesia memiliki wawasan kebangsaan dan wawasan Bhinneka Tunggal Ika yang sama dengan daerah lain di Nusantara, harus berada dalam bingkai falsafah dan konstitusi negara Pancasila dan UUD 1945, jelas tidak ada tawar-menawar dalam hal ini karena terkait dengan keutuhan Republik Indonesia. Dengan tidak mengabaikan akan hal itu, ternyata realitas telah menampakkan nuansa baru dalam memaknai dan menjabarkan arti dari Negara Kesatuan Republik Indonesia itu sendiri khusus untuk Provinsi Aceh, jika seluruh Daerah di Indonesia telah diberikan status Otonomi Khusus, maka Provinsi Aceh telah diberikan Otonomi yang seluas-luasnya untuk menjalankan Syariat Islam. Hal ini terlihat adanya kesempatan besar bagi Provinsi Aceh untuk mencanangkan pembangunan di Provinsi Aceh ke arah yang lebih islami dibanding daerah lain di Nusantara.

Peran yang besar bagi masyarakat untuk berpartisipasi membangun Provinsi Aceh menjadi sebuah provinsi yang berbeda dengan daerah lain di Nusantara jelas melahirkan eksklusifisme Provinsi Aceh dalam wadah negara Kesatuan Republik Indonesia. Eksklusivisme ini sangat rentan dengan asas equality before the law (mempersamakan semua orang di bawah hukum), dan sangat subur dengan pemberian hak-hak istimewa di luar yang berlaku secara umum. Kenyataan seperti ini otomatis akan melahirkan adanya dualisme hukum yang berwawasan nasional dan Bhinneka Tunggal Ika di satu sisi, serta hukum yang berwawasan lokal dan ke-Aceh-an pada sisi yang lain.

Di satu sisi terpahami adanya dualisme Hukum Pidana yang diatur dalam Hukum Pidana Indonesia sebagai sesuatu yang bersifat umum seperti tertuang di dalam KUHP (Kitab Undang Undang Hukum Pidana) yang diatur dengan Undang-Undang Nomor 1 tahun 1946 tentang Kitab Undang-Undang Hukum Pidana termasuk berlaku untuk Provinsi Nangroe Aceh Darussalam karena Aceh adalah bagian integral dari negara kesatuan Republik Indonesia. Tetapi lahirnya Qânûn (Perda) yang berdasarkan Syariat Islam dan dibuat oleh masyarakat Aceh sendiri sebagai sesuatu ketentuan yang lebih khusus karena Aceh telah diberi 
otonomi yang seluas-luasnya untuk menerapkan Syariat Islam berdasar Undang-Undang Nomor 18 Tahun 2001 tentang Otonomi Khusus Provinsi Daerah Istimewa Aceh sebagai Provinsi Naggroe Aceh Darussalam. Penempatan kedua hukum ini sebagai sesuatu yang berhadap-hadapan tentu akan mempertajam pemaknaan terhadap dualisme Hukum Pidana yang diatur dalam KUHP dan juga ketentuan pidana yang diatur dalam Qânûn (Perda) yang ada di Nangroe Aceh Darussalam tersebut. Bahkan dapat mengarah kepada kaburnya asas kepastian hukum, dan keadilan hukum.

\section{Qânûn Jinâyat}

Qânûn merupakan bentuk hukum yang telah menjadi legal formal. ${ }^{7}$ Artinya hukum yang telah memiliki dasar dan teori yang matang dengan melalui dua proses, yaitu proses pembudidayaan hukum dan diformalkan oleh lembaga legislatif,, dengan kata lain, qânûn merupakan hukum positif yang berlaku pada satu negara yang dibuat oleh pemerintah, sifatnya mengikat, dan ada sanksi bagi yang melanggarnya. ${ }^{9}$

Qânûn dalam arti hukum tertulis yang telah diundangkan oleh negara bertujuan untuk: (a) Mendatangkan kemakmuran; (b) Mengatur pergaulan hidup manusia secara damai; (c) Mencapai dan menegakkan keadilan; (d) Menjaga kepentingan tiap-tiap manusia supaya tidak terganggu. ${ }^{10}$

Qânûn atau peraturan perundang-undangan khususnya di Indonesia bersumber pada tiga hukum: hukum kolonial, hukum Islam, dan hukum adat, yang dinamai "trikhotomi" sebagai simbol dari persaingan tiga hukum tersebut.

Di Indonesia pengistilahan qânûn telah masuk ke dalam masyarakat seiring dengan masuknya agama Islam ke bumi Nusantara termasuk ke dalam bahasa Aceh karena salah satu pepatah adat yang menjelaskan hubungan adat dan syariat yang tetap hidup dan bahkan sering dikutip menggunakan istilah ini. Istilah qânûn dalam literatur Melayu Aceh sering diartikan dengan aturan yang berasal dari hukum Islam yang telah menjadi hukum adat. Salah satu naskah tersebut berjudul Qânûn Syara' Kerajaan Aceh yang ditulis oleh Teungku di Mulek pada tahun $1257 \mathrm{H}$ atas perintah Sultan Alaudin

${ }^{7}$ Jasser Auda, Maqasid al Syariyah as Philosophy of Islamic Law a Systems Approach, (The International of Islamic Thought, 2008), h. 59.

${ }^{8}$ Deddy Ismatullah, Materi Kuliah Sejarah Sosial Hukum Islam, tanggal 11 September 2007, h 2.

9 Rachmat Syafe'i, Materi Kuliah Qânûn dan Šyarîah yang dilaksanakan pada tanggal 02 Oktober 2007, h. 3.

${ }^{10}$ C.S.T. Kansil, Pengantar Ilmu Hukum dan Tata Hukum Indonesia, (Jakarta: Balai Pustaka, 1992), h. 13.
Mansyur Syah yang wafat pada tahun 1879 M. Naskah ini berbicara tentang hukum tata Negara, pembagian kekuasaan, badan peradilan dan kewenangan mengadili, fungsi kepolisian dan kejaksaan serta aturan protokoler dalam pelbagai upacara kenegaraan. ${ }^{11}$

Kata qânûn juga berakar dari Bahasa Yunani kanon yang berarti untuk memerintah, tolok ukur atau mengukur. Seiring luasnya penggunaan dalam tradisi formal, artinya meluas menjadi "aturan baku yang diterima oleh sebuah majelis". Bahasa Arab kemudian menyerapnya menjadi qânûn, seperti pada masa kekhalifahanTurki Utsmani, Sultan Sulaiman I dijuluki pemberi hukum (bahasa Turki: Qânûni; bahasa Arab: القانون, al-Qânûnî) karena pencapaiannya dalam menyusun kembali sistem Undang-Undang Utsmaniyah.

Secara gramatikal, kata qânûn berasal dari bahasa Arab dengan asal kata qânûn. Qânûn artinya kompilasi, himpunan peraturan atau Undang-undang, atau norma-norma yang telah mapan.

Al-Ghazali dari golongan fukaha memakai kata qânûn dalam arti kaidah-kaidah umum yang memastikan. Dengan kata lain berarti undang-undang positif suatu negara atau daerah Islam. Contoh qânûn di antaranya Pengaturan Pemerintah Nanggroe Darussalam (NAD) terhadap seluruh bidang Syariah yang mencakup bidang akidah, ibadah, dan syiar Islam yang diatur dalam Qânûn Nomor 10 Tahun 2002 dan Nomor 11 Tahun 2002. Dalam Qânûn ini diatur mulai dari bentuknya sampai sanksi atas pelanggaran terhadapnya.

Di Negara Malaysia, terdapat kodifikasi Hukum Islam yang dinamakan Hukum Qânûn Melaka. Aturan-aturan dalam qânûn tersebut mencakup bidang qishâsh, $\underline{\text { hudûd, }}$ diyyât, ta'zîr, mu'âmalah, hukum perkawinan, hukum pembuktian, hukum acara dan administarsi, dan hukum tentang syarat-syarat penguasa. Begitu pula di Negara Yordania terdapat Undang-undang Perkawinan Nomor

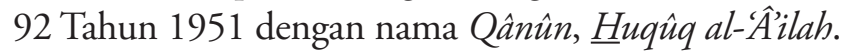

Qânûn berasal dari bahasa Arab adalah seperangkat hukum yang mengaplikasikan pelbagai rincian permasalahan yang diketahui hukumnya. Hal ini senada dengan ungkapan para ulama klasik bahwa qânûn adalah tata aturan yang lengkap dan detil yang didasarkan pada hukum-hukum yang terperinci.

Yusuf al-Qaradhawi menambahkan makna qânûn ketika disandingkan dengan istilah syariah maka ia akan berfungsi sebagai hukum yang diproduksi oleh manusia untuk mengatur kehidupannya dan hubungannya

${ }^{11}$ Al' Yasa Abu Bakar dan Marah Halim, Hukum Pidana Islam di Provinsi Nanggroe Aceh Darussalam, (Banda Aceh: Dinas Syariat Aceh, 2006), h. 6. 
dengan sesama baik secara individu maupun sosial, karenanya ia disebut Qânûn Wadh'̌̀. dari sini dapat dibedakan perbedaan mendasar antara syariah dan qânun adalah jika syariah berasal dari wahyu Allah, maka qânûn merupakan produk atau buatan manusia.

Qânûn yang dalam istilah umum-disebut juga undangundang adalah sekumpulan hukum yang dibuat dengan kasus atau bidang tertentu, semisal undang-undang pidana, dan dijadikan sebagai pedoman dalam menyelesaikan perselisihan diantara masyarakat dan warga negara.

Pasal 1 butir 8 Undang-Undang Nomor 18 Tahun 2001 mendefinisikan qânûn adalah sebagai peraturan daerah, yang menjadi peraturan pelaksanaan undangundang di wilayah Provinsi Aceh dalam rangka penyelenggaraan otonomi khusus.

\section{Dasar Kebijakan Qânûn Jinâyat di Aceh}

Pelaksanaan qânûn Jinâyat di Provinsi Aceh tentu saja memiliki beberapa landasan yuridis, di antaranya: Pertama, Undang-Undang Nomor 44 Tahun 1999 tentang Penyelenggaraan Keistimewaan Provinsi Daerah Istimewa Aceh. Pasal 3 Undang-Undang Nomor 44 tahun 1999 dinyatakan bahwa pelaksanaan Syariat Islam merupakan keistimewaan bagi Aceh. Keistimewaan ini merupakan bagian dari pengakuan bangsa Indonesia yang diberikan kepada daerah karena perjuangan dan nilai-nilai hakiki masyarakat yang tetap dipelihara secara turun temurun sebagai landasan spritiual, moral, dan kemanusiaan. Keistimewaan yang dimiliki Aceh meliputi penyelenggaraan kehidupan beragama, adat, pendidikan, dan peran ulama dalam penetapan kebijakan daerah. ${ }^{12}$

Penyelenggaraan kehidupan beragama yang diwujudkan dalam bentuk pelaksanaan Syariat Islam dilakukan secara menyeluruh. Artinya seluruh dimensi kehidupan masyarakat mendapat pengaturan dari hukum syariat. Pengaturan tersebut meliputi dimensi politik, hukum, ekonomi, pendidikan, kesehatan, sosial budaya, dan lain-lain. Oleh karenanya, hukum yang diberlakukan di Aceh adalah hukum yang bersumber pada ajaran agama, yaitu Syariat Islam. Pertanyaan yang muncul apakah dalam Negara kesatuan Republik Indonesia yang dibenarkan suatu komunitas menjalankan hukum agamanya seperti agama Islam. ${ }^{13}$

Pasal 29 UUD RI tahun 1945 ayat (2) berbunyi, "Negara menjamin kemerdekaan tiap-tiap penduduk untuk memeluk agamanya masing-masing dan untuk

\footnotetext{
${ }^{12}$ Syahrizal, Dimensi Pemikiran Hukum dalam Implementasi Syariat Islam di Aceh, (Aceh: Dinas Syariat Islam, 2007), h. 9.

${ }^{13}$ Syahrizal, Dimensi Pemikiran Hukum, h. 9.
}

beribadat menurut agama dan kepercayaannya itu." Kata "menjamin" dalam Pasal 29 UUD RI tahun 1945 jelas bermakna imperatif. Negara berkewajiban melakukan upaya-upaya agar tiap-tiap penduduk memeluk agama dan beribadat menurut agama dan kepercayaannya itu. Keaktifan Negara di sini adalah memberikan jaminan bagaimana penduduk dapat memeluk dan menjalankan agamanya. ${ }^{14}$ Dalam konteks Syariat Islam di Aceh, negara bukan hanya berperan memfasilitasi kehidupan keagamaan, tetapi juga terlibat mendesain formulasi-formulasi hukum yang bersumber pada ajaran agama Islam melalui kegiatan legislasinya. Keikutsertaan Negara dalam menjalankan Syariat Islam di Aceh sebagai kewajiban konstitusional.

Peran yang ditampilkan negara dalam rangka pelaksanaan Syariat Islam di Aceh, berangkat dari adanya ketentuan UUD tahun 1945 yang mengakui adanya pemerintahan daerah yang bersifat khusus atau istimewa. Provinsi Aceh diberikan keistimewaan salah satunya adalah dengan menjalankan aturan-aturan hukum berdasarkan Syariat Islam. Masyarakat Aceh memang dikenal sebagai masyarakat yang religius dan kental dengan ajaran Syariat Islam dalam menjalankan aktivitas sehari-hari. Norma agama bagi masyarakat Aceh merupakan suatu rujukan atau referensi untuk mengukur apakah suatu perbuatan sesuai atau tidak dengan Syariat Islam. Setiap Muslim meyakini bahwa dengan hidup berdasarkan Syariat Islam akan membawa suatu hidup bahagia selamat dunia akhirat, dengan demikian, pelaksanaan Syariat Islam melalui aturan formal yang ditentukan Negara, ikut memperkuat norma dan ciri khas masyarakat Aceh yang kental dengan ajaran Islam.

Pasal 1 ayat (7) Undang-Undang Nomor 44 tahun 1999 disebutkan bahwa Syariat Islam adalah tuntunan ajaran Islam dalam semua aspek kehidupan. Jadi Syariat Islam yang diberlakukan di Aceh tidak hanya dalam aspek akidah dan ibadah mahbdhah, tetapi juga dalam bidang muamalah dalam arti luas dan bahkan dalam bidang Jinâyat. Dimensi-dimensi Syariat Islam ini ada yang memerlukan kekuasaan Negara dalam pelaksanaannya dalam bidang akidah dan pengamalannya tentu tidak memerlukan kekuasaan Negara untuk penegakannya. Oleh karena itu, pelaksanaan Syariat Islam di Aceh berada dalam kekuasaan Negara, di mana Negara berperan penting dan bertanggung jawab dalam melaksanakan Syariat Islam secara kâffah di Aceh.

Penjelasan resmi Undang-Undang Nomor 44 Tahun 1999 antara lain dinyatakan:

\footnotetext{
${ }^{14}$ Hartono Mardjono, Menegakan Syariat Islam dalam Konteks keIndonesiaan, (Bandung: Mizan, 1997), h. 29.
} 
Isi Keputusan Perdana Menteri Republik Indonesia Nomor 1/Missi/1959 tentang Keistimewaan Provinsi Aceh yang meliputi agama, peradatan dan pendidikan, yang selanjutnya diperkuat dengan Undang-Undang Nomor 22 tahun 1999 tentang Pemerintah Daerah, bahkan disertai dengan penambahan peran ulama dalam menentukan kebijakan daerah. Untuk menindak lanjuti ketentuan-ketentuan mengenai keistimewaan Aceh tersebut dipandang perlu untuk menyusun penyelenggaraan keistimewaan Aceh tersebut dalam suatu undang-undang.

Undang-undang yang mengatur mengenai penyelenggaraan Keistimewaan Provinsi Daeah Istimewa Aceh dalam mengatur urusan-urusan yang telah menjadi keistimewaan melalui kebijakan daerah Undang-undang ono mengatur pelaksanaannya sehingga kebijakan Daerah lebih akomodatif terhadap aspirasi masyarakat Aceh.

Penjelasan Undang-Undang Nomor 44 Tahun 1999 di atas menyatakan bahwa undang-undang tersebut dibuat adalah untuk menjalankan keistimewaan yang diberikan pada tahun 1959 dahulu bahkan ditambah dengan satu keistimewaan lagi, yaitu peran ulama dalam penetapan kebijakan daerah. Mengenai pelaksanaan Syariat Islam pasal 4 menyatakan:

1) Penyelenggaraan kehidupan beragama di daerah diwujudkan dalam bentuk pelaksanaan Syariat Islam bagi pemeluknya dalam bermasyarakat.

2) Daerah mengembangkan dan mengatur penyelenggaraan kehidupan beragama, sebagai mana dimaksud pada ayat (1) dengan tetap menjaga kerukunan hidup antar umat beragama.

Makna atau cakupan Syariat Islam yang akan dilaksanakan dan beberapa istilah lain yang berkaitan dengannya dijelaskan dalam pasal 1 tentang ketentuan umum sebagai berikut:

8. kehidupan beragama, adat, pendidikan dan peran ulama dalam penetapan kebijakan daerah.

9. Kebijakan daerah adalah Peraturan daerah atau keputusan Gubernur yang bersifat mengatur dan mengikat dalam penyelenggaraan keistimewaan.

10. Syariat Islam adalah tuntunan ajaran Islam dalam semua aspek kehidupan.

11. Adat adalah aturan atau perbuatan yang bersendikan Syariat Islam yang lazim dituruti, dihormati, dan dimuliakan sejak dahulu yang dijadikan sebagai landasan hidup.

Berdasarkan penjelasan pasal 1 di atas dapat disimpulkan bahwa: (1) Pemerintah mengakui bahwa keistimewaan yang diberikan kepada Aceh di bidang pendidikan, agama dan peradatan pada tahun 1959 dahulu, tidak mempunyai peraturan pelaksanaannya yang memungkinkannya dijalankan di tengah masyarakat. ${ }^{15}$ Ketiadaan peraturan pelaksanaan tersebut yang ingin dihilangkan yaitu mengeluarkan Undang-Undang

${ }^{15}$ Al Yasa' Abu Bakar, Syariat Islam di Provinsi nanggroe Aceh Darussalam, h. 43.
No. 44 Tahun 1999, lebih kurang 40 tahun setelah keistimewaannya yang diberikan. (2) Syariat Islam yang telah didefinisikan secara relatif lengkap yaitu mencakup seluruh ajarannya. Jadi undang-undang ini telah memberikan pemahaman yang kâffah, kepada Syariat Islam, mencakup ibadah, muamalah, jinayah, munakahah bahkan lebih dari itu mencakup akidah serta akhlak dan semua ajaran dan tuntunan di pelbagai bidang lainnya. Sedang mengenai pendidikan dan peradatan yang dalam pemahaman masyarakat adalah bagian yang tidak terpisahkan dari pelaksanaan Syariat Islam, dalam rumusan undang-undang di dalam penjelasan tentang Syariat Islam, kedua istilah ini tidak lagi dimasukkan. (3) Umat Islam Aceh diberi izin menjalankan Syariat Islam di dalam kehidupannya, sebagai pengakuan atas keistimewaan Aceh. Istilah dalam bermasyarakat yang disebutkan dalam pasal 4 ayat (2) di atas, untuk menegaskan dan menguatkan bahwa Syariat Islam yang akan dilaksanakan di Aceh bukan hanya aturan di bidang ibadat, tetapi mencakup aturan-aturan selebihnya dalam hidup bermasyarakat. Jadi kelihatannya tambahan tersebut dimasukan untuk menguatkan makna kâffah yang ada pada Syariat Islam itu sendiri.

Kedua, Undang-Undang No. 18 Tahun 2001 Tentang Otonomi Khusus bagi Provinsi Daerah Istimewa Aceh. Dalam Undang-Undang Nomor 18 tahun 2001, ada 3 (tiga) bab tentang penegakan hukum yaitu Bab X tentang kepolisian Daerah, Bab XI tentang Kejaksaan Provinsi Aceh. Mengenai Kepolisian, undang-undang menyatakan bahwa tugas fungsional kepolisian di bidang ketertiban dan ketentraman masyarakat di Provinsi Aceh diatur lebih lanjut dengan qânûn Provinsi Aceh sesuai dengan pasal 22 ayat 4 . Sedang mengenal Kejaksaan tidak ada perintah untuk mengaturnya dengan qânûn.

Mengenai Mahkamah Syariah sesuai dengan ketentuan pasal 25 diatur sebagai berikut:

Ayat (1) Peradilan Syariat Islam di Provinsi Aceh sebagai bagian dan sistem peradilan nasional dilakukan oleh Mahkamah Syariah yang bebas dari pengaruh pihak manapun;

Ayat (2) Kewenangan Mahkamah Syariah sebagaimana dimaksud pada ayat (1) didasarkan atas Syariat Islam dalam sistem hukum nasional yang diatur lebih lanjut dengan qânûn Provinsi Aceh;

Ayat (3) Kewenangan sebagaimana dimaksud pada ayat (2) diberlakukan bagi pemeluk agama Islam.

\section{Kedudukan Qânûn Jinâyat di Indonesia}

Kedudukan Qânûn Jinâyat di Provinsi Aceh didasarkan pada Undang-Undang Nomor 18 Tahun 
2001 sebagai landasan pelaksanaan Syariat Islam di Provinsi Aceh saat ini dilanjutkan dengan UndangUndang Nomor Nomor 11 Tahun 2006 tentang Pemerintahan Aceh. Di dalam ketentuan umum angka 21 dan 22 Undang-Undang Nomor 11 Tahun 2006 disebutkan bahwa:

\begin{abstract}
Qânûn Aceh adalah peraturan perundang-undangan sejenis peraturan daerah Provinsi, Kabupaten/kota yang mengatur penyelenggaraan pemerintahan dan kehidupan masyarakat Aceh atau kehidupan masyarakat Kabupaten/kota yang mengatur penyelenggaraaan pemerintahan dan kehidupan masyarakat Aceh atau kehidupan masyarakat kabupaten/kota di Aceh.
\end{abstract}

Undang-Undang Nomor 11 Tahun 2006 kembali menjelaskan tentang kedudukan Qânûn dalam Pasal 233 ayat (1) yang menyatakan "Qânûn dibentuk dalam rangka penyelenggaraan pemerintahan Aceh, pemerintahan Kabupaten/kota dan penyelenggaraan tugas bantuan”, selanjutnya Qânûn nomor 3 Tahun 2007 menyebutkan "Qânûn dibentuk dalam rangka penyelenggaraan pemerintahan Aceh dan Kabupaten/ Kota, pengaturan hal yang berkaitan dengan kondisi khusus daerah penyelenggaraan tugas pembantuan dan penjabaran lebih lanjut peraturan perundangundangan.

Klausul "dalam rangka penyelenggaraan pemerintahan Aceh dan Kabupaten/Kota” sebagai salah satu fungsi pembentukan Qânûn menjadikan Qânûn di Provinsi Aceh berbeda dengan Perda di daerah lainnya di Indonesia. Karena fungsi pembentukan Perda di daerah lain sesuai dengan ketentuan Undang-Undang Nomor 32 Tahun 2004 tentang Pemerintahan Daerah dinyatakan "Perda dibentuk dalam rangka penyelenggaraan otonomi daerah Provinsi/Kabupaten/Kota dan tugas pembantuan.

Fungsi pembentukan Qânûn itu untuk penyelenggaraan pemerintahan Aceh atau Kabupaten/Kota, maka Qânûn dapat mengatur apa saja yang termasuk bentuk penyelenggaraan Pemerintahan Aceh atau Kabupaten/Kota. Urusan Pemerintahan yang menjadi kewenangan Pemerintah Aceh atau Kabupaten/ Kota ini maka Qânûn dapat mengatur apa saja yang termasuk bentuk penyelenggaraan pemerintah Aceh atau Kabuten Kota. Dan Urusan pemerintah ini adalah yang berkaitan dengan pelaksanaan Syariah Islam bagi masyarakat Aceh secara langsung sesuai dengan Pasal 16 ayat (2) huruf a, Undang-Undang Nomor 11 Tahun 2006.

Qânûn dari sisi hierarki perundang-undangan memang sejenis peraturan daerah sesuai dengan ketentuan Undang-Undang Nomor 18 Tahun 2001 maupun Undang-Undang Nomor 11 Tahun 2006, dan peraturan daerah kedudukan paling rendah di- bandingkan peraturan perundang-undangan lainnya berdasarkan Pasal 7 Undang-Undang Nomor 10 Tahun 2004 Jo Undang-Undang Nomor 11 tahun 2011 Tentang Pembentukan Peraturan Perundang-undangan Pasal 7 ayat (1) jenis dan hirarki peraturan perundangundangan sebagai berikut: (a) UUD 1945; (b) Ketetapan MPR; (c) UU/Perpu; (d) Peraturan Pemerintah; (e) Peraturan Presiden; (f) Peraturan Daerah.

Qânûn berdasarkan hierarki peraturan perundangundangan di atas adalah Peraturan daerah di tingkat Provinsi. Dalam Penjelasan Pasal 7 ayat (2) UndangUndang huruf a Undang-Undang Nomor 10 Tahun 2004 disebutkan "termasuk dalam jenis peraturan daerah adalah Qânûn yang berlaku di Provinsi Aceh, terkait dengan kemungkinan dibatalkannya Qânûn pada tingkat Mahkamah Agung, terdapat perbedaan antara Qânûn dengan Perda di daerah lain. Perda di daerah lain dapat dibatalkan oleh Pemerintah melalui peraturan Presiden. Jika Provinsi atau Kabupaten/ Kota tidak menerima terhadap Putusan Pembatalan ini maka Kepada Daerah dapat mengajukan judicial review ke Mahkamah Agung sesuai ketentuan Pasal 114 ayat (1) Undang-Undang Nomor 22 Tahun 1999 Jo Pasal 145 ayat (3 dan 5) Undang-Undang Nomor 3 Tahun 2004, sementara untuk pembatalan Qânûn berdasarkan Undang-Undang Nomor 11 Tahun 2006 maka menjadi kewenangan Mahkamah Agung melalui judicial review berdasarkan Pasal 235 ayat (4). Kewenangan Mahkamah Agung melakukan uji materi ini sesuai dengan kewenangan Mahkamah Agung yaitu menguji peraturan perundang-undangan di bawah Undang-Undang terhadap Undang-Undang.

Wewenang pengujian ini didasarkan pada UndangUndang Dasar Republik Indonesia Tahun 1945 hasil amandemen ketiga yang disebut dalam Pasal 24A ayat (1) "Mahkamah Agung berwenang mengadili pada tingkat Kasasi menguji Peraturan Perundang-undangan di bawah Undang-Undang terhadap Undang-Undang dan mempunyai wewenang lainnya yang diberikan oleh Undang-Undang. Qânûn menjadi suatu yang berbeda dengan Peraturan daerah lainnya di Indonesia disebabkan beberapa pertimbangan. Pertama, Hukum Islam hanya diberlakukan bagi masyarakat Muslim saja. Apabila kita perhatikan isi qânûn yang ada di Provinsi Aceh maka qânûn-qânûn tersebut ada dua macam, yaitu qânûn yang berkaitan dengan pelaksanaan syariat, dan Qânûn non syariat yang berkenaan dengan aspek keduniaan semata. Khusus menyangkut qânûn yang berhubungan dengan pelaksanaan Syariat Islam hanya diberlakukan bagi umat Islam saja, sedang untuk qânun yang non syariat akan berlaku secara umum untuk masyarakat di Provinsi Aceh secara keseluruhan. 
Polarisasi ini tetap dalam kerangka mempertahankan asas kebebasan menjalankan ajaran agama dan kepercayaan masing-masing oleh masyarakat di Aceh.

Qânûn yang berkaitan dengan pelaksanaana Syariat Islam yang ada di Aceh itu menganut asas personalitas keislaman, artinya qânûn-qânûn syariat seperti dikemukakan di atas hanya berlaku bagi umat Islam saja, sedang non Muslim secara umum (Protestan, Katolik, Hindu dan Budha, bahkan penganut aliran Kepercayaan) tidak termasuk di dalamnya, apalagi dipaksa untuk melaksanakannya, jelas tidak mungkin sama sekali. Dengan demikian, bagi penduduk non Muslim di Aceh tidak ada kesulitan untuk tetap tingal di Provinsi Aceh, karena mereka tetap tunduk kepada KUH Pidana sebagai ketentuan hukum yang berlaku secara Nasional, di samping tetap menaati Qânûn yang bersifat non sayariat.

Kesimpulan seperti ini secara jelas dapat dipahami dari: (a) Pasal 25, ayat (3) Undang Undang No.18 Tahun 2001 mengatakan, "Kewenangan sebagaimana dimaksud pada ayat (2) diberlakukan bagi pemeluk agama Islam." 16 (b) Perda No.5 Tahun 2000, pada pasal 2 ayat (2) berbunyi, "Keberadaan agama lain di luar agama Islam tetap diakui di daerah ini, dan pemeluknya dapat menjalankan ajaran agamanya masing-masing." ${ }^{17}$

Sejalan dengan ini, Al Yasa' Abubakar mengatakan bahwa penekanan utama pemberlakuan Syariat Islam di NAD adalah dengan memperhatikan asas personalitas keislaman. Pemaknaan memberlakukan asas personalitas keislaman di sini adalah, Syariat Islam itu hanya diberlakukan bagi masyarakat dengan memperhatikan agama pelaku tindak pidana itu sendiri harus benar-benar beragama Islam, lebih konkrit untuk hal ini bisa dilihat dari Kartu Tanda Penduduk (KTP)-nya, pengamalannya, dan pengakuannya. ${ }^{18}$ Ketegasan ini membuat pengetahuan tentang apa agama pelaku tindak pidana itu di Provinsi Aceh menjadi sangat penting dalam hal penentuan penundukan hukum mereka.

Muslim Ibrahim mengatakan bahwa hukum Islam yang diterapkan di Nanggroe Aceh Darussalam adalah murni berdasarkan Syariat Islam, karenanya hanya diberlakukan bagi umat Islam saja, sedang non Muslim tidak termasuk di dalamnya, soal urusan agama mereka biarlah mereka yang mengaturnya sendiri. Dengan demikian Qânûn sebagai bagian dari hukum Islam yang

16 Dinas Syariat Islam Propinsi NAD, Himpunan Peraturan Perundang-Undangan, h. 26.

17 Dinas Syariat Islam Propinsi NAD, Himpunan Peraturan Perundang-Undangan, h. 58.

${ }^{18}$ Hasil wawancara dengan Kepala Dinas Syariat NAD Al Yasa Abubakar pada tanggal 29-12-2013, UIN Ar-Raniri Banda Aceh. berlaku di NAD hanya diberlakukan bagi umat Islam semata. ${ }^{19}$

Pemberlakuan hukum Islam di Provinsi Aceh yang ada sekarang ini jelas masih berada dalam koridor trilogi kerukunan umat beragama, yaitu kerukunan antar umat beragama, kerukunan intern umat beragama, dan kerukunan antar umat beragama dengan Pemerintah, juga sejalan dengan pedoman dasar dalam beragama bagi bangsa Indonesaia yang diatur pada pasal 29 UUD 1945 tentang kebebasan menjalankan ajaran agama dan kepercayaan masing-masing. Pasal 29 UUD 1945 ayat (1), menyatakan:

Negara berdasar atas Ketuhanan Yang Maha Esa; (2)

Negara menjamin kemerdekaan tiap-tiap penduduk untuk memeluk agamanya masing-masing dan untuk beribadat menurut agamanya dan kepercayaannya itu.

Pasal 29 ayat (1) yang dengan tegas menyatakan "Negara berdasar atas Ketuhanan Yang Maha Esa", pada dasarnya mengandung tiga muatan makna, yaitu: pertama, negara tidak boleh membuat peraturan perundang-undangan atau melakukan kebijakankebijakan yang bertentangan dengan dasar keimanan kepada Tuhan Yang Maha Esa. Kedua, negara berkewajiban membuat peraturan perundang-undangan atau melakukan kebijakan-kebijakan bagi pelaksanaan wujud rasa keimanan kepada Tuhan Yang Maha Esa dari segolongan pemeluk agama yang memerlukannya. Dan ketiga, negara berkewajiban membuat peraturan perundang-undangan yang melarang siapa pun melakukan pelecehan terhadap ajaran agama.

Kata "menjamin" sebagaimana termaktub dalam ayat (2) pasal 29 di atas bersifat "imperatif". Maksudnya, negara berkewajiban secara aktif melakukan upaya-upaya agar tiap-tiap penduduk dapat memeluk agama dan beribadat menurut agama dan kepercayaannya itu. Keaktifan negara di sini adalah untuk memberikan jaminan agar setiap penduduk dapat merdeka menentukan pilihan atas agama yang hendak dipeluknya; dan jaminan agar tiap penduduk dapat menjalankan ibadatnya menurut agama dan kepercayaan yang ditetapkan oleh agama yang dipeluknya. Tentu saja, keaktifan negara bukan untuk menampuri aturan-aturan internal yang telah ditetapkan oleh setiap agama. Jaminan negara atas kemerdekaan tiap penduduk untuk memilih agama yang hendak dipeluknya selama ini tampak tidak pernah menjadi masalah serius. Namun, yang menjadi masalah adalah jaminan negara atas kemerdekaan setiap penduduk untuk menjalankan ibadatnya menurut aturanaturan agama yang dianutnya.

${ }^{19}$ Wawancara dengan Al Yasa' Abu Bakar, pada tanggal 29-12-2013 di UIN Ar-Raniry Banda Aceh. 
Asas personalitas keislaman seperti telah dikemukakan, juga berpedoman kepada Undang-Undang Nomor 18 Tahun 2001, Qânûn Nomor 5 Tahun 2000, dan pernyataan para pakar, hal ini juga telah dipahami benar oleh non Muslim.

Al Yasa' Abu Bakar menjamin bahwa Syariat Islam mengatur dan menjamin hak-hak non Muslim di Provinsi Aceh, jika hal ini memang secara nyata bisa berjalan dengan baik di Provinsi Aceh, pastilah persepsi yang salah di pelbagai pihak tentang pelaksanaan Syariat Islam sebagai suatu alternatif sistem tata kenegaraan yang efektif untuk mencapai kesejahteraan umumakan terkoreksi. ${ }^{20}$

Kedua, Putusan Kasasi dan Peninjauan kembali tidak dalam rangka menentang pemberlakuan hukum Islam. Mahkamah Agung sebagai badan penyelenggara kekuasaan tertinggi di Indonesia hendaknya mendukung penerapan Syariat Islam di Provinsi Aceh. Meskipun sumber rujukan hukum yang digunakan adalah hukum nasional, Mahkamah Agung akan dipahami keliru bila lewat kasasi dan Peninjauan kembali, dia berani membatalkan penerapan hukum Islam di Provinsi Acehdengan mencari alternatif hukum lain.

Logika yang dikembangkan adalah, sikap mengukuhkan putusan Mahkamah Syari'ah, dan Mahkamah Syariah Provinsi di Nanggroe Aceh Darussalam adalah yang paling bijak, berarti Mahkamah Agung telah mempedomani pesan yang diemban oleh UndangUndang Nomor 44 Tahun 1999 tentang Penyelenggaraan Keistimewaan Provinsi Daerah Istimewa Aceh, dan UU No. 18 Tahun 2001 tentang Otonomi Khusus Bagi Provinsi Daerah Istimewa Aceh Sebagai Provinsi Aceh.

Mahkamah Agung harus memutus dalam sidang Kasasi atau Peninjauan Kembali untuk perkara Hukum Pidana Islam dengan berpedoman kepada Qânûn yang sudah dibuat oleh DPRD Provinsi Aceh. Pemahaman seperti di atas dikemukakan sejalan dengan Penjelasan Umum Undang-Undang Nomor 18 Tahun 2001 yang berbunyi:

Hal mendasar dari Undang Undang ini adalah pemberian kesempatan yang lebih luas untuk mengatur dan mengurus rumah tangga sendiri termasuk sumber-sumber ekonomi, menggali dan memberdayakan sumber daya alam dan sumber daya manusia, menumbuh kembangkan prakarsa, kreativitas dan demokrasi, meningkatkan peran serta masyarakat, menggali dan mengimplementasikan tata bermasyarakat yang sesuai dengan nilai luhur kehidupan masyarakat Aceh, memfungsikan secara

${ }^{20}$ Frietz R. Tambunan Pr. Syari' at di Wilayah Syari' at Pernik-Pernik Islam di Nangroe Aceh Darussalam, (Banda Aceh: Dinas Syari at Islam Propinsi Nangroe Aceh Darussalam, Yayasan Ulul Arham, 2002), h. 287-288. optimal Dewan Perwakilan Rakyat Daerah Provinsi NAD dalam memajukan penyelenggaraan pemerintahan di Provinsi NAD dan mengaplikasikan Syariat Islam dalam kehidupan bermasyarakat. ${ }^{21}$

Penjelasan Umum Undang Undang tersebut pada alinea berikutnya, di sana dinyatakan:

Qânûn Provinsi Aceh adalah Peraturan Daerah Provinsi Aceh yang dapat mengenyampingkan peraturan perundang-undangan yang lain dengan mengikuti asas lex specialis derogaat lex generalis, dan Mahkamah Agung berwenang melakukan uji materil terhadap Qânûn. ${ }^{22}$

Ini mengisyaratkan bahwa Mahkamah Agung harus tidak menggunakan hukum yang bersifat umum itu sebagai pedoman dalam memutus pada sidang kasasi untuk perkara yang bersumber dari daerah Provinsi Aceh, tetapi dia mesti berpedoman kepada qânûn, dalam rangka menopang berlakunya hukum Islam yang khusus berlakunya di Provinsi Aceh.

Melalui otonomi Daerah yang digelar di era reformasi ini maka Mahkamah Agung harus menopang setiap produk hukum Daerah dalam rangka memperkokoh makna dari otonomi Daerah tersebut.

Mahkamah Agung misalnya berkeinginan untuk membatalkan hukum Islam yang diberlakukan di Provinsi Aceh itu maka akan sama artinya dengan membatalkan Otonomi Daerah yang Seluas-luasnya bagi Provinsi Aceh itu. Hilangnya kemandirian dan keleluasaan masyarakat Provinsi Aceh untuk memberlakukan Syariat Islam, jelas merupakan sikap pengebirian terhadap perjuangan panjang masyarakat Aceh yang sudah berhasil diraih di era reformasi ini. Bila hal ini yang terjadi berarti Indonesia mundur kembali kepada era sebelum reformasi.

Kedudukan Qânûn dalam sistem hukum di Indonesia berbeda dengan Peraturan daerah yang ada di Indonesia juga didasarkan pada beberapa alasan. Pertama, secara yuridiskedudukan Qânûn di Provinsi Aceh jelas mempunyai kekuatan hukum yang lebih kuat dibandingkan dengan Peraturan daerah lainnya di Indonesia. Hal ini jelas keberadaaan qânûn didasarkan adanya Undang-Undang Nomor 44 Tahun 1999 tentang Keistimewaan Aceh dan Undang-Undang Nomor 18 Tahun 2001. Dari sudut hukum maka Undang-Undang Nomor 44 Tahun 1999 dan UndangUndang Nomor 44 Tahun 1999 merupakan lex specialis yang merupakan aturan hukum khusus yang berlaku di Provinsi Aceh berbeda dengan provinsi lainnya yang berdasarkan Undang-Undang Nomor 22 Tahun

${ }^{21}$ Dinas Syariat Islam Propinsi NAD, Himpunan Peraturan Perundang-Undangan, h. 31.

22 Dinas Syariat Islam Propinsi NAD, Himpunan Peraturan Perundang-Undangan, h. 31. 
1999 dan kemudian diubah menjadi Undang-Undang Nomor 32 Tahun 2004.

Qânûn dalam kaitan pelaksanaan hukum Jinâyat di Provinsi Aceh didasarkan pada pasal 2 ayat (1) dan (2) Undang-Undang Nomor 44 Tahun 1999 tentang Keistimewaan Provinsi Aceh. Namun demikian Undang-Undang ini dianggap masih mengandung kelemahan, karena Peraturan Daerah yang tercantum sama dengan Peraturan Daerah yang ada di Provinsi lainnya di Indonesia, sehingga ketentuan dalam perda tidak mempunyai kekuatan hukum yang kuat dalam hal pemberian sanksi bagi para pelanggar termasuk bagi para pelanggar Syariat Islam khususnya bidang Jinâyat. Apalagi dalam pasal 2 Undang-Undang Nomor 44 Tahun 1999 hanya mengatur Perda tingkat Kabupaten/ Kota dan tidak mengatur Perda di tingkat Provinsi.

Kelemahan yang terdapat dalam Undang-Undang ini, pada akhirnya melahirkan Undang-Undang Nomor 18 Tahun 2001 yang mendudukan posisi qânûn lebih tinggi dibandingkan dengan Peraturan Daerah yang ada di Provinsi lainnya di Indonesia. Undang-Undang Nomor 18 Tahun 2001 ini menentukan bahwa qânûn yang dimaksud adalah Peraturan Daerah di Provinsi Aceh dan dapat mengesampingkan peraturan lainnya dengan memakai asas lex specialis derogaat lex generalis meskipun Mahkamah Agung memang dapat melakukan uji materi terhadap Qânûn.

Al Yasa Abu Bakar berpandangan bahwa qânûn ini merupakan Perda Plus setara dengan Peraturan Pemerintah, karena qânûn dapat dilaksanakan secara langsung dengan memakai asas lex specialis. Rusjdi Muhammad memiliki pandangan yang lain karena baginya kedudukan qânûn tetap setara dengan Peraturan Daerah, karena lex specialis yang terdapat dalam qânûn hanya berlaku sama dengan peraturan yang sederajat dengan qânûn yaitu peraturan daerah, sehingga qânûn itu tidak sama kedudukannya dengan Undang-Undang.

Argumentasi tentang qânûn memiliki kedudukan yang sama dengan Peraturan Daerah memang dapat dibuktikan dengan alasan yuridis, yaitu dalam penjelasan umum Undang-Undang Nomor 18 Tahun 2001 yaitu Mahkamah Agung berwenang melakukan uji materil terhadap qânûn. Penyerahan uji materil qânûn kepada Mahkamah Agung tentu saja menjadi dasar bahwa sesungguhnya qânûn memang sama kedudukannya dengan Peraturan Daerah, karena seandainya qânûn itu sama dengan Undang-Undang maka hak uji materil terhadap qânûn itu tentu saja diserahkan kepada MPR sesuai dengan Pasal 5 ayat (1) dan (2) TAP MPR Nomor III/2000 dan pada akhirnya hak uji materil terhadap Undang-Undang menjadi kewenangan Mahkamah Konstitusi sesuai Pasal 10 ayat (1) huruf a Undang-Undang Nomor 24 Tahun 2003 tentang Mahkamah Konstitusi jo pasal 12 ayat (1) dan (2) Undang-Undang Nomor 4 Tahun 2004.

Kedudukan qânûn memang tidak bisa disamakan dengan Undang-Undang, karena pemaknaan qânûn sendiri dalam Undang-Undang Nomor 18 Tahun 2001 sendiri yang menyebutkan qânûn merupakan Perda. Karena itu dari sisi hierarki perundang-undangan sebagai lex specialis yang harus disamakan adalah Undang-Undang Nomor 18 Tahun 2001 bukan qânûn itu sendiri. Undang-Undang itulah yang menyamakan kedudukannya dengan Undang-Undang lainnya. Oleh karenanya apabila qânûn misalnya secara substansi berlawanan dengan Undang-Undang maka hal tersebut dapat dibenarkan secara yuridis selama qânûn yang diatur tersebut merupakan kewenangan Pemerintah Provinsi Aceh berdasarkan ketentuan Undang-Undang Nomor 18 Tahun 2001.

Qânûn dari sisi proses pembentukannya merupakan produk legislatif yang ada di daerah sementara Peraturan Pemerintah apalagi Undang-Undang merupakan produk legislatif di tingkat Pemerintah pusat sesuai dengan Pasal 10 ayat (3) Undang-Undang Nomor 32 Tahun 2004. Karena itu sesuai teori hierarki maka ketentuan peraturan yang lebih rendah tidak boleh bertentangan dengan ketentuan peraturan yang lebih tinggi. Hal ini didasarkan pada ketentuan Pasal 4 TAP MPR Nomor III/2000 menyebutkan "sesuai dengan Tata urutan Perundang-undangan, maka setiap aturan perundang-undangan ini, maka setiap aturan yang lebih rendah tidak boleh bertentangan dengan aturan hukum yang lebih tinggi.

Ketentuan dalam TAP MPR Nomor III/2000 sekarang sudah dicabut menjadi menjadi UndangUndang RI Nomor 10 Tahun 2004 dalam Pasal 7 ayat (5) disebutkan bahwa "Kekuatan hukum peraturan perundang-undangan adalah sesuai dengan hierarki sebagaimana yang dimaksud dalam ayat (1) UndangUndang RI Nomor 10 Tahun 2004 dan diubah menjadi Undang-Undang Nomor 12 Tahun 2012 tentang Pembentukan Peraturan Perundang-undangan.

Undang-Undang Nomor 12 Tahun 2012 Pasal 9 ayat (1) yang menentukan bahwa dalam hal suatu undang-undang diduga bertentangan dengan UndangUndang Dasar 1945 maka pengujiannya dilakukan oleh Mahkamah Konstitusi, sementara dalam ayat (2) menentukan bahwa apabila dalam hal suatu peraturan perundang-undangan di bawah undang-undang bertentangan dengan undang-undang pengujiannya dilakukan oleh Mahkamah Agung. 
Dalam konteks Provinsi Aceh maka teori hierarki dengan asas lex superior derogate lex inferior (Peraturan yang lebih rendah tidak boleh bertentangan dengan peraturan yang lebih tinggi) dibatasi oleh asas lex specialis derogat lex generalis (Peraturan yang khusus dapat membatalkan peraturan yang lebih umum). Keberadaan Qânûn di Provinsi Aceh sesungguhnya menjadi kuat karena mendapat perintah langsung dari Undang-Undang yakni Undang-Undang Nomor 18 Tahun 2001 yang merupakan lex specialis dari UndangUndang Nomor 32 Tahun 2004 tentang Pemerintahan Daerah. Begitu pula berkaitan dengan qânûn tentang Syariat Islam merupakan pelaksanaan dari UndangUndang Nomor 18 Tahun 2001 Pasal 25 yang telah menentukan bahwa:

\footnotetext{
Ayat (1) Peradilan Syariat Islam di Provinsi Aceh sebagai bagian dari sistem peradilan nasional dilakukan oleh Mahkamah Syariyyah yang bebas dari pengaruh pihak manapun.

Ayat (2) Kewenangan Mahkamah Syar'iyah sebagaimana ayat (1) didasarkan atas Syariat Islam dalam sistem hukum nasional, yang diatur lebih lanjut dengan Qânûn Provinsi Aceh.
}

Kekuatan qânûn pada tahap berikutnya semakin kuat dengan adanya Undang-Undang Nomor 11 Tahun 2006 yang mencabut Undang-Undang Nomor 18 Tahun 2001 tentang Pemerintahan Aceh. Pada ketentuan umum Undang-Undang Nomor 11 Tahun 2006 angka 21 dan 22 disebutkan bahwa Qânûn Aceh adalah peraturan perundang-undangan sejenis peraturan daerah provinsi, Kabupaten/kota yang mengatur penyelenggaraan pemerintahan dan kehidupan masyarakat Aceh atau kehidupan masyarakat Aceh atau kehidupan masyarakat Kabupaten/kota di Aceh.

Sesungguhnya Peraturan Daerah tentang Syariat Islam sesungguhnya bertabrakan dengan UndangUndang Nomor 22 Tahun 1999 Jo. Undang-Undang Nomor 32 Tahun 2004. Undang-Undang tersebut mengamanatkan bahwa domain masalah agama merupakan kewenangan Pemerintah Pusat melalui lembaga DPR. Pasal 7 Undang-Undang Nomor 22 Tahun 1999 mengatur "Kewenangan daerah mencakup kewenangan seluruh bidang pemerintahan kecuali kewenangan dalam bidang politik luar negeri, pertahanan keamanan lain".

Peraturan daerah yang bernuansa syariah tetap terbuka sesuai dengan bunyi penjelasan UndangUndang tersebut yaitu khusus di bidang keagamaan sebagian kegiatannya dapat ditugaskan oleh Pemerintah kepada daerah sebagai upaya meningkatkan keikutsertaan daerah dalam menumbuhkembangkan kehidupan beragama. Begitu pula secara yuridis akan ada kepastian hukum, karena Islam sebagai suatu ajaran mengandung sistem nilai sebagaimana yang termaktub dalam Alquran dan Hadis.

Kedua, secara sosiologis penduduk Indonesia mayoritas Muslim khususnya di Provinsi Aceh menunjukan secara tidak langsung sesungguhnya mereka telah mengamalkan ajaran Islam dalam kehidupan sehari-hari. Meskipun kadar penerimaan hukum Islam itu sendiri bertingkat-tingkat, namun demikian Islam menjadi nilai yang dominan dalam kehidupan seharihari, baik dalam kandungan spiritual, bahasa, budaya, praktik perilaku sampai pada pelaksanaan Syariat Islam itu sendiri. Hukum Islam sudah menjadi living law dalam masyarakat. Maka integrasi hukum Islam ke dalam hukum nasional di dalam masyarakat Aceh ditambah kesadaran pengamalan ajaran beragama, maka hukum Islam menjadi alternatif terbaik untuk mengatasi komplikasi kehidupan hukum.

Ketiga, secara filosofis hukum Islam memiliki kandungan yang sarat dengan tema keadilan. Islam yang dalam ajarannya juga mengandung aturan-aturan hukum adalah sistem ajaran sekaligus metodologi pencapaiannya, karena setiap bangsa memiliki cita-cita yang sama dan universal, berupa keadilan, ketertiban, perdamaian, keserasian, kesucian, dan lain sebagainya. Aturan ini tentu saja sesuai dengan kebutuhan manusia yang hidup dimuka bumi ini.

\section{Penutup}

Kedudukan Qânûn Jinâyat Aceh dalam pembaruan Hukum Pidana di Indonesia sudah sesuai dengan hukum di Indonesia, berdasarkan: (a) Pasal 29 UndangUndang Dasar Negara Republik Indonesia tahun 1945, agar setiap bangsa Indonesia mengamalkan ajaran agamanya masing-masing; (b) Pancasila sila pertama Ketuhanan yang Maha Esa, yang berarti setiap orang harus mengamalkan ajaran agama sesuai dengan keyakinan yang dianut; (c) Tinjauan Negara hukum Indonesia, maka kedudukan Qânûn sudah sesuai dengan aturan Negara hukum Indonesia, karena Qânûn sudah diatur berdasarkan Undang-Undang Nomor 18 tahun 2001 tentang otonomi khusus Pemerintahan Aceh, dan Undang-Undang Nomor 11 tahun 2006 tentang Pemerintahan Aceh; dan (d) Adanya Qânûn yang mengatur masalah pidana di Provinsi Aceh merupakan pembaharuan Hukum Pidana di Indonesia, karena hukum yang baik harus mencerminkan hukum yang hidup dalam masyarakat itu sendiri, sehingga hukum yang berlaku di Aceh sekarang ini bisa dijadikan model pembangunan hukum di Indonesia yang majemuk, namun tetap dalam bingkai Negara hukum Indonesia.[] 


\section{Pustaka Acuan}

A. M. Datuk Marhun Batuah dan D.K. Bagindo Tananeh, Hukum Adat dan Adat Minangkabau, Jakarta: N.V. Poesaka Asli, 1992.

Abu Bakar, Al Yasa dan Halim, Marah, Hukum Pidana Islam di Provinsi Aceh, Banda Aceh: Dinas Syariat Aceh, 2006.

Aceh, Abubakar, Sejarah Syiah di Indonesia, Jakarta: Islamic Research Institute, 1977.

Ahmad, Kamaruzzaman Bustamam, Islam Historis Dinamika Studi Islam di Indonesia, , Yogyakarta: Galang Press, 2002.

Ali, Muhammad Daud, Hukum Islam, UUPA dan Masalahnya, dalam Cik Hasan Bisri, Bunga Rampai Peradilan Agama di Indonesia, Bandung: Ulil Albab Press, 1997.

Amanwinata, Rukmana, "Sistem Pemerintahan Indonesia”, Dialektika, Vol. 2, No. 2-2001.

"Pengaturan dan Batas Implementasi Kemerdekaan Berserikat Dan Berkumpul Dalam Pasal 28 UUD 1945”, Disertasi, Bandung: Pascasarjana Universitas Padjadjaran, 1996.

Auda, Jasser, Maqasid al Syariah as Philosophy of Islamic Law a Systems Approach, The International of Islamic Thought, 2008.

Basah, Sjachran, Eksistensi dan Tolok Ukur Badan Peradilan Administrasi di Indonesia, Bandung: Penerbit Alumni, Cet. ke-1, 1985.

Hasjmy, Ali, Syiah dan Ablussunah Saling Merebut Kekuasaan dalam Kerajaan Aceh Darussalam, Jakarta: Bulan Bintang, 1983.
Iqbal, Muhammad Zafar, Kafilah Budaya pengaruh Persia Terhadap Kebudayaan Indonesia, Jakarta: Citra, 2006.

Ismail, Azman, Syariat Islam di Nanggroe Aceh Darussalam, Aceh: Dinas Syariat Aceh, 2006.

Ismatullah, Deddy, "Materi Kuliah Sejarah Sosial Hukum Islam", tanggal 11 September 2007.

Kansil, C.S.T., Pengantar Ilmu Hukum dan Tata Hukum Indonesia, Jakarta: Balai Pustaka, 1992.

Manan, Abdul, Reformasi Hukum Islam di Indonesia, Jakarta: Raja Grafindo Persada, 2006.

Mardjono, Hartono, Menegakan Syariat Islam dalam Konteks keIndonesiaan, Bandung: Mizan, 1997.

O'Rourke, Kevin, Reformasi: the Struggle for Power in Post-Soeharto Indonesia. Australia: Allen \& Unwin, 2002.

Soekanto, Soerjono, Perspektif Teoritis Studi Hukum dalam Masyarakat, Jakarta: Rajawali,1985.

, Soerjono, Pokok-pokok Sosiologi Hukum, Jakarta: Rajawali, 1991.

Syahrizal, Dimensi Pemikiran Hukum dalam Implementasi Syariat Islam di Aceh, Aceh: Dinas Syariat Islam, 2007.

Tambunan Pr, Frietz R., Syariat di Wilayah Syariat Pernik-Pernik Islam di Nangroe Aceh Darussalam, Banda Aceh: Dinas Syariat Islam Provinsi Nangroe Aceh Darussalam, Yayasan Ulul Arham, 2002.

Wahjono, Padmo, Sistem Hukum Nasional dalam Negara Hukum Pancasila, Jakarta: Penerbit CV. Rajawali, Cet. Ke-2, 1983. 